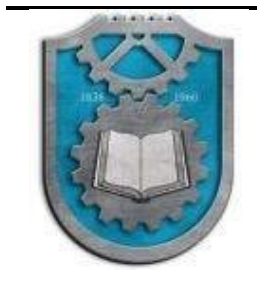

MOBILITY \& VEHICLE MECHANICS

DOI: $10.24874 / \mathrm{mvm} .2021 .47 .02 .04$

UDC: 620.178 .16

\title{
ANALYSIS OF INFLUENCING FACTORS ON BRAKE WEAR AND NON- EXHAUST EMISSION WITH REFERENCE TO APPLIED MATERIALS IN BRAKE PADS
}

\author{
Saša Vasiljević ${ }^{1}$, Jasna Glišović ${ }^{2}$, Blaža Stojanović ${ }^{3}$, Nadica Stojanović ${ }^{4}$, Ivan Grujić $^{5}$ \\ Received in July $2020 \quad$ Revised in August $2020 \quad$ Accepted in September 2021 \\ RESEARCH ARTICLE
}

\begin{abstract}
Wear of the elements of the brake friction pair and particle emission caused by the operation of the brakes (non-exhaust emissions) is one of the biggest polluters of the environment from traffic and a problem that needs to be solved in the coming period. The brake pads are made of a mixture of different materials that ensure the longevity and efficiency of the brake system. The applied materials have different wear intensities in certain operating conditions, but wear is influenced by different factors that have been analyzed by other authors in their research. An overview of materials in brake pads, as well as their influence on wear and non-exhaust emission based on modern research is performed in this paper.
\end{abstract}

KEY WORDS: brakes, influencing factors, materials, wear, particles

(C) 2021 Published by University of Kragujevac, Faculty of Engineering

\footnotetext{
${ }^{I}$ Saša Vasiljević, MSc.,Teaching assistant, Academy of Professional Studies Šumadija Department in Kragujevac, Kosovska 8. Str., 34000 Kragujevac, Serbia, vasiljevic.sasa036@ gmail.com (*Corresponding author)

${ }^{2}$ Jasna Glišović, PhD., assoc. prof., University of Kragujevac, Faculty of Engineering, 6 Sestre Janjić Str., 34000 Kragujevac, Serbia, jaca@kg.ac.rs

${ }^{3}$ Blaža Stojanović, PhD., assoc. prof., University of Kragujevac, Faculty of Engineering, 6 Sestre Janjić Str., 34000 Kragujevac, Serbia, blaza@kg.ac.rs

${ }^{4}$ Nadica Stojanović, MSc., Teaching assistant, University of Kragujevac, Faculty of Engineering, 6 Sestre Janjić Str., 34000 Kragujevac, Serbia, nadica.stojanovic@kg.ac.rs

${ }^{5}$ Ivan Grujić, M.Sc., Teaching assistant, University of Kragujevac, Faculty of Engineering, 6 Sestre Janjić Str., 34000 Kragujevac, Serbia, ivan.grujic@kg.ac.rs
} 


\title{
ANALIZA UTICAJNIH FAKTORA NA HABANJE KOČNICA I NON- EXHAUST EMISIJU SA OSVRTOM NA PRIMENJENE MATERIJALE U KOČNIM PLOČICAMA
}

REZIME: Habanje elemenata frikcionog para kočnice i emisija čestica koje nastaje radom kočnica (non-exhaust emisija) predstavlja jedan od najvećih zagađivača okruženja od saobraćaja i problem koji je potrebno rešiti u narednom periodu. Kočne pločice su sačinjene od mešavine različitih materijala koji obezbeđuju dugotrajnost i efikasnost kočnog sistema. Primenjeni materijali imaju različit intenzitet habanja $u$ određenim radnim uslovima, ali na habanje utiču različiti faktori koji su u analizirani od strane drugih autora u njihovim istraživanjima. U ovom radu izvršen je pregled materijala u kočnim pločicama, kao i njihov uticaj na habanje i non-exhaust emisiju na osnovu savremenih istraživanja.

KLJUČNE REČI: kočnice, uticajni faktori, materijali, habanje, čestice

\section{ANALYSIS OF INFLUENCING FACTORS ON BRAKE WEAR AND NON- EXHAUST EMISSION WITH REFERENCE TO APPLIED MATERIALS IN BRAKE PADS}

\author{
Saša Vasiljević, Jasna Glišović, Blaža Stojanović, Nadica Stojanović, Ivan Grujić
}

\section{INTRODUCTION}

Wear of the friction elements of the braking system leads to environmental pollution, creating the so-called non-exhaust emission of particles, which occurs due to the wear of two surfaces that are in contact with each other. The harmfulness of the particles formed by the wear of brake materials is reflected in the fact that the friction elements of the brakes are often composed of substances that are harmful to human health [1,2]. The problem and the reason for the harmfulness is that the particles are released into the environment, and they also contain harmful substances that a person inhales through the air [3, 4]. Some of the materials are so harmful that their use is slowly declining in brake pads or is completely banned such as asbestos. Asbestos is very harmful to human health, so it is no longer used in most countries, but it also has very good tribological properties $[5,6]$. It is important to note that today we are moving towards finding alternative materials that would replace harmful substances, and in addition to maintaining the efficiency and durability of the brake elements. Non-exhaust particle pollutants are sources that emit particles by their wear, i.e. wear of the contact surfaces of the elements, but do not emit particles by some combustion process as emitted by the engine. Brakes are one of the sources of non-exhaust emission. In addition to the wear of the brakes, non-exhaust particles are also created by the wear of other parts and elements of the vehicle, e.g. tires, various metal assemblies such as joints, gears, couplings, ... Today, with strict legal restrictions on exhaust emissions and the increasing use of electric vehicles, these sources are becoming the dominant source of particles, especially when it comes to brakes. The problem in the case of application of friction materials, i.e. materials used for the production of brake pads, is that there may be changes in the braking coefficient (brake efficiency), but also the intensity of brake wear [7]. So it is very important to take care of the applied materials, but in addition, extensive tests are necessary. The reason for this is that the brake pads as well as the disc must meet two key requirements, and that is a high value of the coefficient of friction, but a low wear rate of friction materials [8]. The applied materials, i.e. the composition of the brake pads and the material from which the disc is made, have a great influence on these two key 
requirements. The conclusion is that when analyzing brake wear and particle formation, materials have a significant impact, but it is important to note that wear is also affected by operating conditions, i.e. different parameters and quantities that can be analyzed when it comes to the braking process. In order to identify the influence of various parameters or factors on brake wear, this paper reviews some of the factors that affect brake wear. In addition, this paper presents an analysis of the most commonly used materials used in brake pads, but also those researchers have found to be the most present in particles.

\section{CHARACTERISTIC AND MOST COMMONLY APPLIED MATERIALS IN THE COMPOSITION OF BRAKE FRICTION PAIRS}

The brake pads contain different materials, each with its own specific role, so they can be classified in several ways. With this in mind, the materials used in brake pads are divided into several groups:

- Friction additives - which determine the friction properties of brake pads and contain a mixture of abrasives.

- $\quad$ Fillers - which reduce costs and improve the workability of brake pads.

- Binder - which holds the brake pad components together.

- Reinforced fibers that provide mechanical strength [9].

When it comes to materials, today, more and more research is being done on alternative materials that could be used in brake pads, which is present in the works of several authors. Thus, in [10], examples of some of the materials that could be used in exchange for a longer material that is more harmful are presented. One of the goals is that such materials have as little harmfulness as possible, i.e. that their wear creates particles that do not have a harmful effect on humans [11]. The properties of brake pads that are pursued in the process of product development and achieving a quality product are: a high coefficient of friction, favorable thermal conductivity, high thermal resistance, low mass, high resistance to wear, low noise level, low cost, not making the damage to the brake surface of the metal element of a friction pair, and corrosion resistance, [12]. Table 1 shows some of the natural materials tested that could be applied in brake pads.

Table 1 Investigated alternative materials that could be used in brake pad

\begin{tabular}{|l|l|}
\hline Reference & Alternative material \\
\hline Olupona et al.[13] & Cocoa bean shells \\
\hline Singaravelu et al. [14] & Crab shell powder \\
\hline Ademoh and Adeyemi [15] & Maize Husks \\
\hline Idris et al. [16] & Banana peels \\
\hline Olabisi et al. [17] & $\begin{array}{l}\text { Palm kernel shells cocoa beans shells, } \\
\text { maize husks }\end{array}$ \\
\hline Primaningtyas et al. [18] & Rice husk \\
\hline
\end{tabular}


to applied materials in brake pads

\begin{tabular}{|l|l|}
\hline Lagel et al. [19] & Tannins furanic resin \\
\hline Bretotean et al. [20] & Coconut fiber \\
\hline
\end{tabular}

Today, there are a number of materials used in friction pads. According to the source [21], the composition of sixty-five commercial brake pads and fifteen brake discs used on motor vehicles was analyzed. Using XRF method (X-ray fluorescence) for material analysis, the composition of these pads was performed and Table 2 shows the elements that are part of the brake pad material.

Table 2 Results of composition analysis of 65 brake pads and 15 discs [21]

\begin{tabular}{|l|l|l|l|l|l|}
\hline Element & Unit & Maximum & Minimum & Average & $\begin{array}{l}\text { Number of } \\
\text { samples }\end{array}$ \\
\hline \multicolumn{5}{|c|}{ Materials used in brake pads } \\
\hline $\mathrm{Fe}$ & $\% \mathrm{~m} / \mathrm{m}$ & 44.7 & 8.4 & 22.7 & 65 \\
\hline $\mathrm{Cu}$ & $\% \mathrm{~m} / \mathrm{m}$ & 17.8 & 0.11 & 11.2 & 65 \\
\hline $\mathrm{Zn}$ & $\% \mathrm{~m} / \mathrm{m}$ & 18.0 & 0.09 & 4.7 & 65 \\
\hline $\mathrm{Sn}$ & $\% \mathrm{~m} / \mathrm{m}$ & 8.9 & 0.01 & 3.3 & 65 \\
\hline $\mathrm{Al}$ & $\% \mathrm{~m} / \mathrm{m}$ & 5.2 & 0.42 & 1.7 & 65 \\
\hline $\mathrm{Si}$ & $\% \mathrm{~m} / \mathrm{m}$ & 5.2 & 0.05 & 1.8 & 65 \\
\hline $\mathrm{Zr}$ & $\% \mathrm{~m} / \mathrm{m}$ & 7.1 & 0.00 & 1.2 & 57 \\
\hline $\mathrm{Ti}$ & $\% \mathrm{~m} / \mathrm{m}$ & 12.1 & 0.02 & 0.9 & 65 \\
\hline $\mathrm{Sb}$ & $\% \mathrm{~m} / \mathrm{m}$ & 8.3 & 0.01 & 2.7 & 29 \\
\hline $\mathrm{Cr}$ & $\% \mathrm{~m} / \mathrm{m}$ & 2.1 & 0.04 & 0.8 & 65 \\
\hline $\mathrm{Mo}$ & $\% \mathrm{~m} / \mathrm{m}$ & 4.0 & 0.00 & 0.8 & 50 \\
\hline $\mathrm{Mn}$ & $\% \mathrm{~m} / \mathrm{m}$ & 2.4 & 0.10 & 0.3 & 65 \\
\hline $\mathrm{V}$ & $\% \mathrm{~m} / \mathrm{m}$ & 1.7 & 0.01 & 0.3 & 62 \\
\hline
\end{tabular}




\begin{tabular}{|c|c|c|c|c|c|}
\hline $\mathrm{Ni}$ & $\% \mathrm{~m} / \mathrm{m}$ & 0.4 & 0.05 & 0.1 & 38 \\
\hline $\mathrm{Bi}$ & $\mathrm{mg} / \mathrm{kg}$ & 10,949 & 0.00 & 2060 & 65 \\
\hline $\mathrm{W}$ & $\mathrm{mg} / \mathrm{kg}$ & 9863 & 0.00 & 1825 & 65 \\
\hline $\mathrm{P}$ & $\mathrm{mg} / \mathrm{kg}$ & 8750 & 0.00 & 1225 & 65 \\
\hline $\mathrm{Pb}$ & $\mathrm{mg} / \mathrm{kg}$ & 53,681 & 0.16 & 1305 & 65 \\
\hline Co & $\mathrm{mg} / \mathrm{kg}$ & 4564 & 0.00 & 196 & 65 \\
\hline \multicolumn{6}{|c|}{ Materials used in brake disc } \\
\hline $\mathrm{Fe}$ & $\% \mathrm{~m} / \mathrm{m}$ & 93.7 & 92.0 & 92.9 & 15 \\
\hline $\mathrm{Al}$ & $\% \mathrm{~m} / \mathrm{m}$ & 0.9 & 0.5 & 0.6 & 15 \\
\hline $\mathrm{Si}$ & $\% \mathrm{~m} / \mathrm{m}$ & 2.4 & 1.7 & 2.0 & 15 \\
\hline $\mathrm{Zr}$ & $\% \mathrm{~m} / \mathrm{m}$ & 0.01 & 0.003 & 0.004 & 3 \\
\hline $\mathrm{Cr}$ & $\% \mathrm{~m} / \mathrm{m}$ & 0.3 & 0.1 & 0.2 & 15 \\
\hline Mo & $\% \mathrm{~m} / \mathrm{m}$ & 0.2 & 0.005 & 0.031 & 15 \\
\hline $\mathrm{Mn}$ & $\% \mathrm{~m} / \mathrm{m}$ & 0.8 & 0.5 & 0.6 & 15 \\
\hline $\mathrm{Ni}$ & $\% \mathrm{~m} / \mathrm{m}$ & 0.1 & 0.1 & 0.1 & 4 \\
\hline $\mathrm{Bi}$ & $\mathrm{mg} / \mathrm{kg}$ & 9.6 & 0.1 & 5.2 & 15 \\
\hline W & $\mathrm{mg} / \mathrm{kg}$ & 9.2 & 0.1 & 4.4 & 15 \\
\hline $\mathrm{P}$ & $\mathrm{mg} / \mathrm{kg}$ & 578.5 & 0.2 & 73.7 & 15 \\
\hline $\mathrm{Pb}$ & $\mathrm{mg} / \mathrm{kg}$ & 9.6 & 0.0 & 4.8 & 15 \\
\hline $\mathrm{Co}$ & $\mathrm{mg} / \mathrm{kg}$ & 8.3 & 0.9 & 4.7 & 15 \\
\hline
\end{tabular}

When it comes to specific materials that can be found in particles, a number of authors have tried to find and analyze, which are the dominant elements that indicate that the particles of non-exhaust emissions originated precisely from the braking system. Thus, Table 3 shows the materials that are characteristic of the wear of the braking system, and that can be found in the fractions of the particles, and according to the results obtained by different authors.

Table 3 Characteristic materials in non-exhaust source monitoring as dominant elements in brake pairs 

to applied materials in brake pads

\begin{tabular}{|l|l|}
\hline Reference & Material \\
\hline Hulskotte et al.[21] & $\mathrm{Fe}, \mathrm{Cu}, \mathrm{Zn}$ и $\mathrm{Sn}$ \\
\hline Lawrence et al. [22] & $\mathrm{Ba}, \mathrm{Cu}, \mathrm{Fe}, \mathrm{Mn}, \mathrm{Ni}, \mathrm{Pb}, \mathrm{Sb}$ \\
\hline Mosleh et al.[23] & $\mathrm{Al}, \mathrm{Mg}, \mathrm{Sb}, \mathrm{Si}, \mathrm{S}$ и Cu \\
\hline Bukowiecki et al. [24] & $\mathrm{Cu}, \mathrm{Fe}, \mathrm{Mo}, \mathrm{Sb}, \mathrm{Sn}, \mathrm{Zn}, \mathrm{Zr}$ \\
\hline Adamiec et al.[25] & $\mathrm{Ti}, \mathrm{Cr}$ and Cu \\
\hline Duong and Lee [26] & $\mathrm{Cu}, \mathrm{Ni}$ \\
\hline Alves et al. [27] & $\mathrm{Ba}, \mathrm{Cu}$ \\
\hline Adachi and Tainosho [28] & $\mathrm{Ba}, \mathrm{Ce}, \mathrm{Cu}, \mathrm{Fe}, \mathrm{La}, \mathrm{Sb}, \mathrm{Ti}, \mathrm{Y}, \mathrm{Zr}$ \\
\hline Valotto et al. [29] & $\mathrm{Fe}, \mathrm{Cr}, \mathrm{Sb}$ and Mo \\
\hline
\end{tabular}

Having in mind the existence of different elements in the brake pads, they can be divided into several categories according to their composition in different ways. It is important to note that one of the divisions that can be found most often, according to the content of metals, i.e. metallic materials. Thus, according to the composition of the brake pads can be divided into:

- metallic brake pads,

- $\quad$ semi-metallic brake pads,

- low-metallic brake pads,

- $\quad$ asbestos brake pads, asbestos-free brake pads (NOA- Non-Asbestos Organic),

- carbon brake pads,

- $\quad$ ceramic brake pads [30].

Metal brake pads usually contain only elemental metals and graphite as a lubricant [31]. Semi-metal friction linings are one of the most wear-resistant brake pads and therefore, the most durable. Such brake pads contain metals that are combined with graphite and other fillers in order to maintain their resistance to wear but also to have as little impact on the disc as possible [32]. According to the source [33] they contain 35 to $65 \%$ of metals while according to the source [32] they contain 30 to $70 \%$ of metallic materials while according to [14] from 30 to $60 \%$ of metals. Low metal brake pads according to the source [35] contain $10-30 \%$ of metallic materials. According to the source [33], organic friction linings consist of materials obtained from organic origin, such as glass, Kevlar, resin or rubber. Organic friction linings or NAO (Non-Asbestos Organic) have replaced asbestos substances due to health risks. These friction linings contain less than $10 \%$ metal [36], but the rest of the friction material comes from plant-derived fibers, high-temperature resins and other materials. These friction linings are intended for light vehicles and normal driving 
conditions and modes [37]. Ceramic friction plates are primarily made of ceramic material with copper reinforcing fibers [33]. Fine copper fibers used in ceramic friction coatings are applied, in order to increase their friction and thermal conductivity [32]. Ceramic brake calipers have a longer service life and good temperature stability [35], but have the lowest wear rate, have a favorable effect on disc wear and produce the least noise [34]. A more detailed and clear overview of the composition of some of the brake pads is given in Table 4 , where, based on data of various authors, a presentation of the composition of the brake pads is formed.

Table 4 Division of brake pads according to the percentage of metals they contain in their composition

\begin{tabular}{|l|l|l|}
\hline Type of brake pad & Reference & Percentage of metal materilas \\
\hline Metallic brake pads & Banait et al. [31] & Graphite and metals \\
\hline \multirow{2}{*}{$\begin{array}{l}\text { Semi-metalic brake } \\
\text { pads }\end{array}$} & Brigestone [32] & $30-70 \%$ \\
\cline { 2 - 3 } & Grigoratos and Martini [38] & Up to 65\% \\
\cline { 2 - 3 } & Bonfanti[36] & $>50 \%$ \\
\hline \multirow{2}{*}{$\begin{array}{l}\text { Low metal brake } \\
\text { pads }\end{array}$} & Grigoratos and Martini [38] & $10-30 \%$ \\
\cline { 2 - 3 } & Bonfanti [36] & $10-50 \%$ \\
\hline \multirow{2}{*}{$\begin{array}{l}\text { Non-asbestos organic } \\
\text { brake pads (NAO) }\end{array}$} & Bonfanti [36] & $<10 \%$ \\
\cline { 2 - 3 } & Ma et al. [39] & $\begin{array}{l}\text { Dont contain very low } \\
\text { percentage of metals }\end{array}$ \\
\hline
\end{tabular}

\section{FACTORS AFFECTING BRAKE WEAR AND PARTICULATE FORMATION}

When it comes to the factors that affect the brake wear, Ausburg et al. [40] illustrated the factors that lead to wear and thus the formation of particles. A graphic representation according to this author is shown in Figure 1. Rudnytskyj [41] came to similar results of influential factors, where it is stated that contact area, running-in, transfer-film, load, sliding velocity and temperatures affects the brake wear. According to the authors [12], the friction between friction pair elements and their wear are influenced by the complex combination of the speed changes, temperature increase, load and braking energy. 


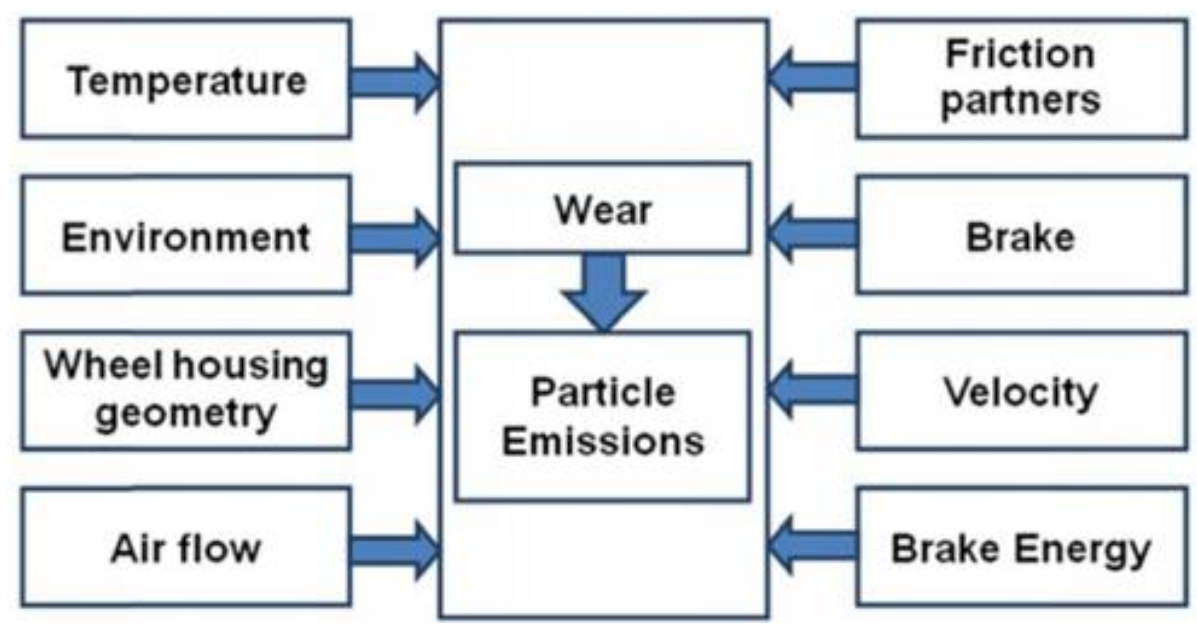

Figure 1 Factors influencing particle formation [40]

Based on the research [42], it was found that the wear rate of brake pads made from different materials, but also the friction between the elements of friction pairs is mostly influenced by the following characteristics or factors:

- Braking conditions: brake pressure, initial braking speed, braking time, increase in braking temperature, etc.,

- Material characteristics: physical, chemical and mechanical friction properties, etc.,

- Characteristics of friction surfaces: surface roughness, contact properties, etc.,

- Operating conditions: ambient temperature, humidity, air flow and so on,

- Structural parameters: shape, size and contact mode of a brake pair, etc.

The temperature at the contact surface has a significant effect on brake wear. With an increase in temperature, there is also an increase in the wear rate of the brakes, but also an increase in the concentration of the formed particles, as evidenced by the results of research $[43,44]$. Based on research and results [31], it was found that asbestos pads have the lowest thermal conductivity and with the increase in the percentage of metal in the brake pads, the thermal conductivity, so the temperature itself increases. Thus, Figure 2 shows the different brake pads and their conductivity, where it can be seen that metal brake pads have the highest thermal conductivity. 


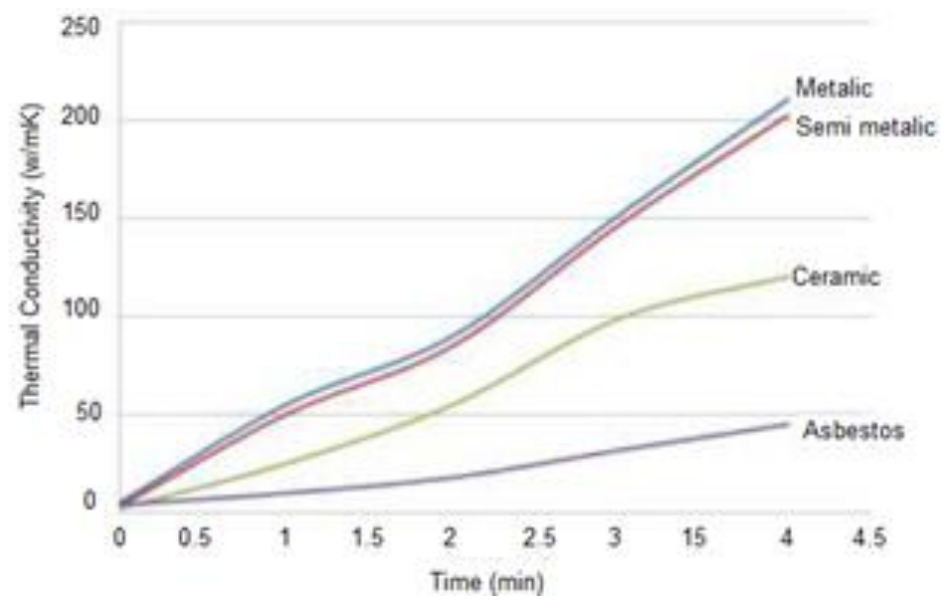

Figure 2 Thermal conductivity of different brake pad types [31]

Relying on research [31], it was also found that the load or pressure in the contact surface between the elements of brake pair has a significant impact on the wear rate, but also the wear rate varies depending on the type of brake pad. The results are shown in Figure 3, where it is clearly noticeable that the metal brake pads have the highest wear rate and this increases with increasing load.

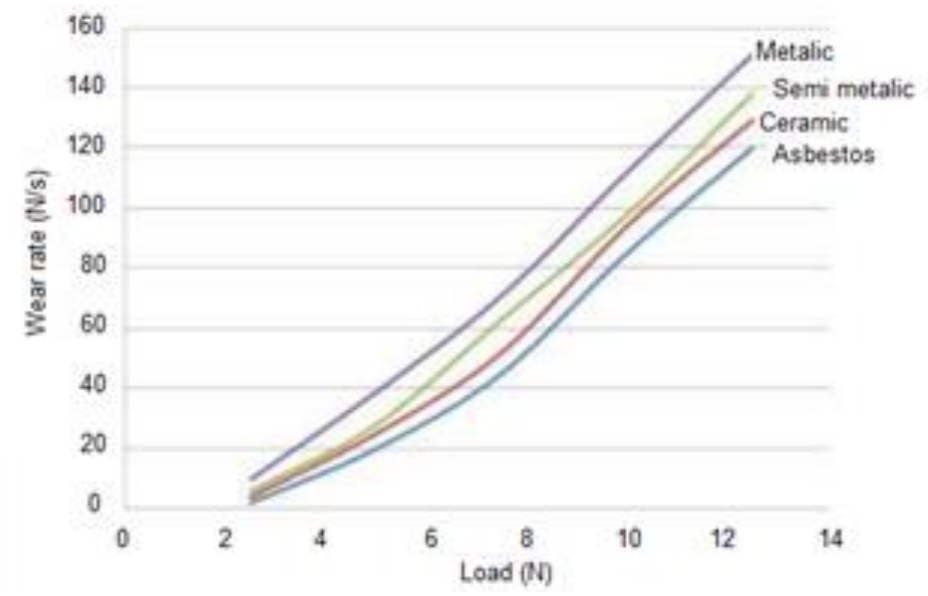

Figure 3 Wear rate versus load for different brake pad types [31]

Similar results on the influence of load on the rate of brake wear were obtained in $[45,46]$ for organic and metallic brake pads. In both cases, there was an increase in the wear rate with an increase in brake pressure. However, according to the source [47], the wear rate of organic brake pads is higher than in the case of wear of metallic friction pads. By road tests according to the reference [48], three types of brake pads (organic, semi-metallic and ceramic tiles) were studied in three test modes, and it was concluded that organic friction pads wear the most and lose weight, while semi-metal brake pads have lost the least weight. The characteristics of the materials themselves and the method of production of brake pads also have a significant impact on the wear of brake pads. Thus, the porosity of the material 
and the hardness of the brake pads have a significant effect on the wear of the brake pads and the formation of particles. When it comes to the porosity of brake pads, the more porous the brake pads, the higher is the wear rate. This examination of the brake pads showed that brake pads with higher hardness have a higher degree of brake wear [47]. The wear rate of brakes is also significantly influenced by the sliding length of the brake pads on the contact surface of the brake disc [49]. Studies [50, 51], in which organic and metallic friction pads were used, have shown that the wear rate is influenced by the disc rotation speed, i.e. the initial speed at which the braking process begins. In the study [52], the phenomena that occur in the contact surface between the disc, and the friction pads were analyzed. Thus, it was found that changing the sliding speed between the contact surfaces of the brake pairs, and the pressure in the contact surface leads to a change in the concentrations of the formed particles. Furthermore, the increase in pressure and sliding speed leads to an increase in the concentration of the formed particles. Similar results were obtained in the study [53]. But, according to the results of tests [47], it was found that an increase in the sliding speed between the friction materials leads to a decrease in the wear rate of the material. Particle formation also depends on the deceleration, as well as the initial velocity or rotation speed of the disc [54]. By increasing the initial velocity and deceleration, the particle concentration of both $\mathrm{PM}_{10}$ and $\mathrm{PM}_{2.5}$ also increases. Also, in the source [54], it was proved that many more particles are released after braking and re-accelerating the disc, bearing in mind that then the particles are released from the friction surfaces of the brake. It has even been found that drum brakes are more environmentally friendly, bearing in mind that the particles are retained inside the drum, while with disc brakes, they are released directly into the environment. Similar results were obtained in [55], where it was determined that the amount of particles formed and the wear of the friction elements of the brake depend on the speed and deceleration. Braking and complete stopping at a speed of $50 \mathrm{~km} / \mathrm{h}$ creates $40-100 \%$ more particles than when braking at a speed of $30 \mathrm{~km} / \mathrm{h}$. Humidity is also one of the factors that can affect the wear rate of brake pads and discs, which was found in a study [56], where it was concluded that with increasing humidity, the wear rate of semi-metallic and organic brake pads decreases. However, in research [57], it was concluded that the increase in humidity also increases the wear rate of brake pairs. It is certainly always necessary to take into account the applied brake pads and the materials used, but still this parameter is very important considering that it varies in operation of vehicles or brakes.

\section{CONCLUSIONS}

The brakes are the emitter of particles that is considered to be one of the most influential participants in the non-exhaust emission of vehicles. The formation of particles in this case is caused by the wear of elements of friction pair, i.e. brake disc and brake pads. The problem is much more serious due to the fact that brake pairs often contain metals or other materials that wear out and become part of the particles, i.e. they are in particle fractions. In that case, with the heavy-metal content, the particles become very harmful to human health and the environment. Brake pads often contain different elements such as $\mathrm{Fe}, \mathrm{Cu}, \mathrm{Zn}, \mathrm{Al}$, $\mathrm{Mg}, \mathrm{Sb}, \mathrm{Si}, \mathrm{Ti}, \mathrm{Cr}$. Such elements in brake pads are characterized as the most commonly used materials. Bearing in mind that brake pads often contain metals, which otherwise have a harmful effect on humans, brake pads are divided into several categories according to the percentage of metal material in the mass of one brake pad. In order to reduce the harmfulness of particles and brake pads, alternative natural materials that would replace metals or some other harmful substances are increasingly being tested. Brake wear is affected by a number of factors and quantities that occur during the braking process. The problem is that all parameters are as complex as the braking process. A large number of 
authors have examined the influence of different parameters on brake wear rate and particle formation. Some of these factors are the temperature in the contact surface of the friction pairs, the pressure between the friction pairs, the humidity, the sliding speed, the sliding length ... It is important to note that with the change of all parameters, there is also a change in the wear rate of the brakes and the concentration of the formed particles. The applied materials in the brake pads certainly have an important influence, so all parameters can have a different influence depending on the composition of the brake pads.

\section{ACKNOWLEDGMENTS}

This paper was realized within the framework of the project "The research of vehicle safety as part of a cybernetic system: Driver-Vehicle-Environment”, ref. no. TR35041 funded by the Ministry of Education, Science and Technological Development of the Republic of Serbia.

\section{REFERENCES}

[1] Glišović, J., Pešić, R., Vasiljević, S., Stojanović, N., Grujić, I.: "Road vehicle as a source of non-exhaust particulate matter", Proceedings of 14th International Conference on Accomplishments in Mechanical and Industrial Engineering DEMI 2019, Banja Luka, 2019, pp. 585-590, ISBN 978-99938-39-85-9.

[2] Gasser, M., Riediker, M., Mueller, L., Perrenoud, A., Blank, F., Gehr, P., \& RothenRutishauser, B.: „Toxic effects of brake wear particles on epithelial lung cells in vitro“. Particle and Fibre Toxicology, 2009, Vol. 6, No. 1, p. 30.

[3] Alemani, M., Wahlström, J., Olofsson, U.: „On the influence of car brake system parameters on particulate matter emissions“, Wear, 2018, pp. 67-7, pp. 396-397.

[4] Glišović, J., Lukić, J., Stojanović, B., Stojanović, N.: “Airborne wear particles from automotive brake systems in urban and rural areas", 13th International Conference on Accomplishments in Mechanical and Industrial Engineering-DEMI 2017, Banja Luka, Repubika Srpska, 2017, pp. 717-722, ISBN 978-99938-39-72-9.

[5] Shinde, D., Mistry, K. N.: "Asbestos base and asbestos free brake lining materials comparative study" International Journal of Scientific World, 2017, Vol. 5, No. 1, p. 47.

[6] Lemen, R. A., "Asbestos in brakes: Exposure and risk of disease" American Journal of Industrial Medicine, 2004, Vol. 46, No. 3.

[7] Darius, G. S., Berhan, M. N., David, N. V., Shahrul, A. A., Zak, M. B.: "Characterization of brake pad friction materials", WIT Transactions on Engineering Sciences, 2015, Vol. 51.

[8] Nagesh, S. N., Siddaraju, C., Prakash, S. V., Ramesh, M. R.: "Characterization of Brake Pads by Variation in Composition of Friction Materials", Procedia Materials Science, 2014, 5, pp. 295-302.

[9] Chan, D., Stachowiak, G. W.: "Review of automotive brake friction materials", Proceedings of the Institution of Mechanical Engineers, Part D: Journal of Automobile Engineering, 2014, Vol. 218, No. 9, pp. 953-966.

[10] Umamaheswara, R., Babji, R.: "A Review paper on alternate materials for Asbestos brake pads and its characterization", International Research Journal of Engineering and Technology (IRJET), 2015, Vol. 2, No. 2, pp. 556-562.

[11] Manocha, L. M., Prasad, G., Manocha, S.: "Carbon-Ceramic Composites for Friction Applications”, Mechanics of Advanced Materials and Structures, 2013, Vol. 21, No. 3 , pp. 172-180. 
to applied materials in brake pads

[12] Gupta, B., Jashvantlal, A.: "Review of automotive brake friction materials", International Journal of Advance Engineering and Research Development, 2015, Vol. 2, No. 2, pp. 218-223.

[13] Olupona A., Abodunwa A., Fayoyin K.: „Performance and Organ Weights of Laying Hens Fed Diets Containing Graded Levels of Sun-dried Cocoa Bean Shell“ (CBS). International Journal of Poultry Science, 2011, 10, pp. 987-990.

[14] Singaravelu, D. L., Ragh M., R., R., V., Manoharan, S., Kchaou, M. (2019): „Development and Performance Evaluation of Eco-Friendly Crab Shell Powder Based Brake Pads for Automotive Applications“. International Journal of Automotive and Mechanical Engineering, 2019, Vol. 16, No. 2, pp. 6502-6523.

[15] Ademoh, N., Adeyemi, O: „Development and Evaluation of Maize Husks (AsbestosFree) Based Brake Pad. Industrial Engineering Letters, 2015, Vol. 5, No. 2, pp. 67-80.

[16] Idris, U. D., Aigbodion, V. S., Abubakar, I. J., Nwoye, C. I.: „Eco-friendly asbestos free brake-pad: Using banana peels“. Journal of King Saud University - Engineering Sciences, 2015, Vol. 27, No. 2, pp. 185-192.

[17] Olabisi A, Ademoh N, Boye T.: „Development of asbestos-free automotive brake pad using ternary agro-waste fillers“. Journal of Multidisciplinary Engineering Science and Technology, 2016, Vol. 3, No. 7, pp. 5307- 5323.

[18] Primaningtyas, W. E., Sakura, R. R., Suheni, Syafi'i, I., Adhyaksa, A. A. G. A. D.: „Asbestos-free Brake Pad Using Composite Polymer Strengthened with Rice Husk Powder“. IOP Conference Series: Materials Science and Engineering, 2019, 462, p. 012015.

[19] Lagel, M. C., Hai, L., Pizzi, A., Basso, M. C., Delmotte, L., Abdalla, S., Al-Marzouki, F. M.: „Automotive brake pads made with a bioresin matrix“. Industrial Crops and Products, 2016, 85, pp. 372-381.

[20] Bretotean CP, Craciun AL, Josan A, Ardelean E.: „Experimental Study of Sintered Friction Material with Coconut Fiber for Brake Pads“. Materiale Plastce, 2018, Vol. 55, No. 3, pp. 389-392.

[21] Hulskotte, J. H. J., Roskam, G. D., Denier van der Gon, H. A. C.: "Elemental composition of current automotive braking materials and derived air emission factors", Atmospheric Environment, 2014, 99, pp. 436-445.

[22] Lawrence, S., Sokhi, R., Ravindra, K., Mao, H., Prain, HD., Bull, ID.: „Source apportionment of traffic emissions of particulatematter using tunnel measurements“. Atmospheric Environment 2013, 77, pp. 548-557.

[23] Mosleh, M., Blau, J., Dumitrescu, D.: „Characteristics and morphology of wear particles from laboratory testing of disk brake materials“. Wear, 2004, 256, pp. 11-12, pp. 1128-1134.

[24] Bukowiecki, N., Gehrig, R., Lienemann, P., Hill, M., Figi, R., Buchmann, B., Furger, M., Richard, A., Mohr, C., Weimer, S., Prévôt, A., Baltensperger, U.: „PM10 emission factors of abrasion particles from road traffic (APART)“. Swiss Association of Road and Transportation Experts (VSS), 2009.

[25] Adamiec, E., Jarosz-Krzemińska, E., Wieszała, R.: „Heavy metals from non-exhaust vehicle emissions in urban and motorway road dusts". Environmental Monitoring and Assessment, 2016, Vol. 188, No. 6, p. 369.

[26] Duong, T. T. T., Lee, B.-K.: „Determining contamination level of heavy metals in road dust from busy traffic areas with different characteristics“. Journal of Environmental Management, 2011,Vol. 92, No. 3, pp. 554-562. 
[27] Alves, D. D., Riegel, R. P., Klauck, C. R., Ceratti, A. M., Hansen, J., Cansi, L. M., Osório, D. M. M.: „Source apportionment of metallic elements in urban atmospheric particulate matter and assessment of its water-soluble fraction toxicity“. Environmental Science and Pollution Research, 2020, doi:10.1007/s11356-020-077918.

[28] Adachi, K., Tainosho, Y.: „Characterization of heavy metal particles embedded in tire dust“. Environment International, 2004, 30, pp. 1009-1017.

[29] Valotto, G., Zannoni, D., Rampazzo, G., Visin, F., Formenton, G., Gasparello, A.: „Characterization and preliminary risk assessment of road dust collected in Venice airport (Italy)“. Journal of Geochemical Exploration, 2018, 190, pp. 142-153.

[30] Brake pad typs, http://www.suscon.org/pdfs/bpp/pdfs/OEBrakePads.pdf, accessed: 28.01.2021.

[31] Banait, A. S., Raibhole, V. N.: "Study on Tribological Investigations of Alternative Automotive Brake Pad Materials", 8th National Conference on "Recent Developments in Mechanical Engineering" [RDME-2019], 2019, pp. 40-43.

[32] Brigestone, comparative analysis of different friction linings, https://www.bridgestonetire.com/tread-and-trend/drivers-ed/ceramic-vs-metallicbrake-pads, посећено: 28.01.2021.

[33] Comparative analysis of different friction linings, https://www.floorjackshop.com/best-type-of-brake-pads-ceramic-vs-semi-metallic-vsorganicl, accessed: 28.01.2021.

[34] Разлике између различитих фрикционих облога, https://www.autoevolution.com/news/brake-pads-organic-ceramic-and-semi-metallicwhat-are-the-differences-112665.html, accessed: 29.01.2021.

[35] Valor, ceramic brake pads, https://valorbrakes.com/ceramic-brake-pads-2/, accessed: 02.02.2021.

[36] Bonfanti, A.: „Low-impact friction materials for brake pads“. PhD Thesis, University of Trento, Trento, Italy, 2016.

[37] Type of brake pads, https://www.matfoundrygroup.com/News\%20and\%20Blog/Types_of_Brake_Pads_an d_Which_Should_You_Use, посећено: 28.01.2021.

[38] Grigoratos, T., Martini, G.: „Brake wear particle emissions: a review“. Environmental Science and Pollution Research, 2014, Vol. 22, No. 4, pp. 2491-2504.

[39] Ma, Y., Martynková, G. S., Valášková, M., Matějka, V., Lu, Y.: „Effects of ZrSiO4 in non-metallic brake friction materials on friction performance“. Tribology International, 2008, Vol. 41, No. 3, pp. 166-174.

[40] Augsburg, K., Gramstat, S., Horn, R., Sachse, H.: „Measures Development for Brake Dust Emissions with Computational Fluid Dynamics and Particle Imaging Velocimetry“. SAE Technical Paper Series, 2011.

[41] Rudnytskyj, A.: „Simulations of contact mechanics and wear of linearly reciprocating block-on-flat sliding test". Degree project, Luleå University of Technology Department of Engineering Sciences and Mathematics, 2018.

[42] Xiao, X., Yin, Y., Bao, J., Lu, L., Feng, X.: "Review on the friction and wear of brake materials", Advances in Mechanical Engineering, 2016, Vol. 8, No. 5.

[43] Alemani, M., Nosko, O., Metinoz, I., Olofsson, U.: „A Study on Emission of Airborne Wear Particles from Car Brake Friction Pairs", SAE International Journal of Materials and Manufacturing, 2015, Vol. 9, No. 1, pp. 147-157. 
[44] Nosko, O., Olofsson, U.: „Effective density of airborne wear particles from car brake materials", Journal of Aerosol Science, 2017, 107, pp. 94-106.

[45] Bao, J., Zhu, Z., Tong, M., Yin, Y., Peng, Y.: "Influence of braking pressure on tribological performance of non- asbestos brake shoe for mine hoister during emergency braking”, Industrial Lubrication and Tribology, 2012, Vol. 64, No. 4, pp. 230-236.

[46] Wang, L., Li, Y., Guo, XH.: "Study on friction and wear property of train powder metallurgy brake disc", Locomotive and Rolling Stock Technolgy, 2008, 5, pp. 27-28.

[47] Ria, T., Soib, M., Kasir, R.: "Selection of Best Formulation for Semi-Metallic Brake Friction Materials Development. Powder Metallurgy, 2012.

[48] Bahrom, M., Roslin, E., Arzmi, M., Zainal M.: "Evaluation of Wear in Aftermarket Brake Pads for Enhancing Braking Performance in a Passenger Vehicle", International Journal on Advanced Science, Engineering and Information Technology, 2016, Vol. 6, No. 4, pp. 553-556.

[49] Olofsson, U., Olander, L., Jansson, A.: "A Study of Airborne Wear Particles Generated From a Sliding Contact", Journal of Tribology, 2009, Vol. 131, No. 4.

[50] Han, XM., Gao, F., Song, BW.: "Effect of friction speed on friction and wear performance of Cu-matrix friction materials", Tribology, 2009, 29, pp. 89-96.

[51] Deng, H., Li, K., Li, H., Wang, P., Xie, J., Zhang, L.: "Effect of brake pressure and brake speed on the tribological properties of carbon/carbon composites with different pyrocarbon textures", Wear, 2010, Vol. 270, No. 1-2, pp. 95-103.

[52] Olofsson, U., Olander, L., Jansson, A.: "A Study of Airborne Wear Particles Generated From a Sliding Contact", Journal of Tribology, 2009, Vol. 131, No. 4, pp. 503-1.

[53] Shorowordi, K., Haseeb, A. S. M., Celis, J.: "Velocity effects on the wear, friction and tribochemistry of aluminum MMC sliding against phenolic brake pad", Wear, 2004, Vol. 256, No. 11-12, pp. 1176-1181.

[54] Hagino, H., Oyama, M., Sasaki, S.: Airborne brake wear particle emission due to braking and accelerating. Wear, 2015, pp. 334-335, pp. 44-48.

[55] Chasapidis, L., Grigoratos, T., Zygogianni, A., Tsakis, A., Konstandopoulos, A. G.: „Study of Brake Wear Particle Emissions of a Minivan on a Chassis Dynamometer“, Emission Control Science and Technology, 2018, Vol. 4, No. 4, pp. 271-278.

[56] Mirzababaei, S., Filip, P.: „Impact of humidity on wear of automotive friction materials“, Wear, 2017, pp. 376-377, pp. 717-726.

[57] Blau, P. J., McLaughlin, J. C.: „Effects of water films and sliding speed on the frictional behavior of truck disc brake materials“, Tribology International, 2003, Vol. 36, No. 10, pp. 709-715. 
Intentionally blanc 